\title{
Selective and Elective Surgeries During COVID-19 Epidemics
}

\author{
$\underline{\text { Hassan Moayeri }}^{1}$, Anvar Elyasi ${ }^{2}$ \\ 1.Assistant Professor, Department of Surgery, School of Medicine, Kurdistan University of Medical Sciences, Sanandaj, \\ Iran., (Corresponding Author), Tel: 087-33227890, Email: Moaiery@ gmail.com, ORCID ID: 0000-0003-3221-476X \\ 2.Assistant Professor, Department of Surgery, School of Medicine, Kurdistan University of Medical Sciences, Sanandaj, \\ Iran. ORCID ID: 0000-0003-4434-6604
}

\begin{abstract}
Background and Aim: Covid-19 is spreading in the world and the governments are taking further steps to curb the rate of virus infection. Increase in the number of cases of Covid-19 has led to a challenging condition and we have to decide to decrease or stop elective surgeries.

Materials and Methods: Using keywords of elective surgery, emegent surgery, coronavirus, Covid 19, we searched Persian and international databases (SID Magiran, Iranmedex, Google Scholar, Medline, Scopus, Elsevier, Pubmed, Sciencedirect) for the related English or Persian studies. Finally, we selected 31 articles.

Results: All hospitals and surgeons must draw up a plan to limit, postpone or cancel elective scheduled operations, endoscopy, or other invasive procedures until the necessary health care facilities and measures for the patients are available.

Conclusion: During the current Covid-19 epidemic protection of hospital resources such as hospital beds and ICUs, respirators, and patients and staff is necessary. It is recommended that hospitals stop elective surgeries. Accurate clinical judgment should be considered as the determinative factor in performing operations
\end{abstract}

Keywords: Elective Surgery, Emegent Surgery, COVID-19, Medical judgment

Received: Apr 14, 2020

Accepted: Feb 14, 2021

How to cite the article: Hassan Moayeri, Anvar Elyasi. Selective and Elective Surgeries During COVID-19 Epidemics. SJKU. 2020;26 (2):93-102.

Copyright (C) 2018 the Author (s). Published by Kurdistan University of Medical Sciences. This is an open access article distributed under the terms of the Creative Commons Attribution-Non Commercial License 4.0 (CCBYNC), where it is permissible to download, share, remix, transform, and buildup the work provided it is properly cited. The work cannot be used commercially without permission from the journal 


\section{جراحىهاى انتخابى (الكتيو) و ضرورى در طى همهكيرى COVID-19}

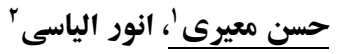

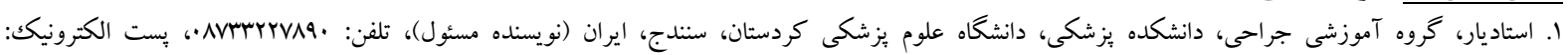

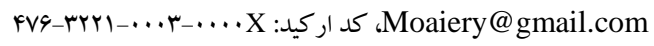

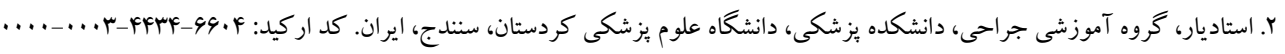
زمينه و هدف: از آنجا كه كوويد 19، در سرتاسر جهان در حال انتشار است، دولتها در حـال انجـام اقـدامات فزاينـدهاى بـراى محدود كردن ميز ان آلود گى ويروس هستند. با افزايش تعداد بيمارى انجام اعمال جراحى الكتيو يا غير اورزانسى بـا جـالث جـدى مواجه خواهيم شد. مواد و روشها: اين مطالعه مرورى با بررسى مطالعات مرتبط با موضوع مورد مطالعه كه به زبان انخليسى يا فارسى به رشته تحرير آمده بودند وارد ئزوهش ما شدند. كليدوازههاى مورد استفاده شامل جراحى انتخابى، جراحى اضطرارى، كرونـا ويسروس، كوويـــ

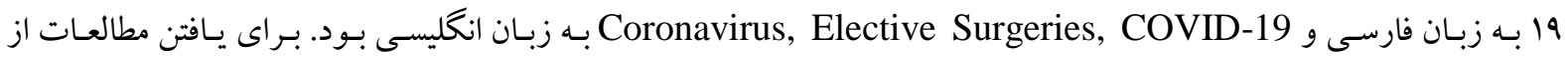

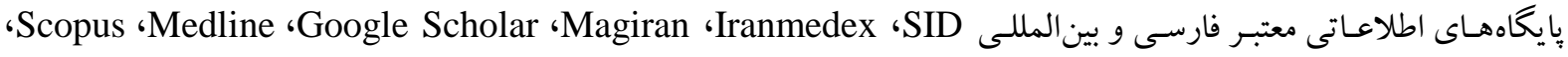
Science Direct ،PubMed ،Elsevier يافته ها: هر بيمارستان و جراح بايد با طرحى براى به حداقل رساندن، به تعويق انداختن يا لغـو عملهـاى برنامهريزىشـده انتخـابى (الكتيو)، آندوسكويى يا ساير روش هاى تهاجمى اقدام كند تازمـانى كـه از زيرسـاخت هاى بهداشـتى و مراقبتى بيمـاران اطمينـان حاصل شود. نتيجه كيرى: در طول همه كيرى فعلى كوويد 19 براى محافظت از منابع مراقبتى و درمانى مانند تخت بيمارستان و ICU، دستخاه تنفس و بيمار ان و كار كنان، بهطور كلى توصيه شده است كه بيمارستانها جراحىهاى انتخابى را متوقف كنــد در حسالى كه هيـيج جيز جايخزين قضاوت بالينى صحيح بزشكى و تصميم گيرى موردى نخواهد بود. وازههاى كليدى: جراحى انتخابى، جراحى اضطرارى، كوويد 19، قضاوت بالينى

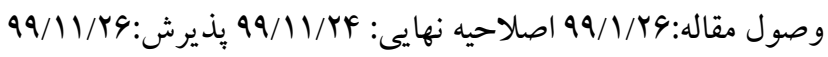


طول بيمارى همـه گير COVID-19 را تشـديد كرد (F, ץ). بسيارى از بيمارستانها براى لغو كليه جراحسىهـاى انتخـابى در كشور آمريكا اقدام كردند(ه). عدم امكان بيش بينى دوره زمانى بانسدمى (عـالمخير شـدن) بيمارى و شيوع يا زمان دقيق كنترل COVID-19 حاكى از اين است كه بيماران ممكن است از دسترسى به مراقبتهاى جراحى بهموقع كه احتمـالاً بـراى مـــت نـامعلومى، محـروم شوند. احتمالاً لغو عمل هاى جراحى انتخـابى، ممكـن اسـت تأثير جشمخًر و بـىسابقهاى بر سلامت جامعه ما داشته باشــ و عوارض و مرگكومير ناشى از ايسن تـأخير ممكـن اسـت از مرگك و مير بيمارى كرونا ويروس نيز فراتر بـرود. بـه لحـاظ

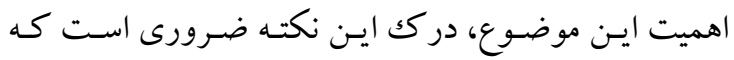
اصطلاح "جراحى انتخابى" به معناى جراحى اختيارى نيست،

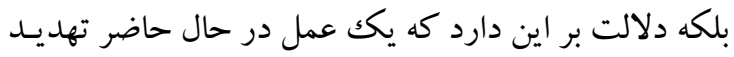

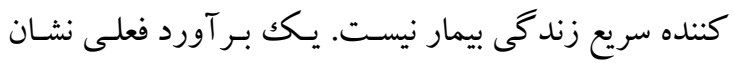
مىدهد كه بيش از •هـ/ از كل موارد جراحى انتخابى ، ايـن

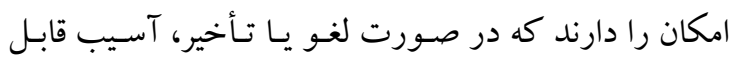
تـوجهى بـه بيمـاران وارد كنـــ(9). وضسعيت فيزيولـوزيكى برخى از گروههاى آسيب يذير از بيمـاران در صسورت عـدم مراقبت جراحى مناسب ممكن است به سرعت بــتر شـود و تأخير آن در سلامتى بيماران احتمالاً باعث مىشود كه آنها

در برابر عفونت كرونا ويروس آسيب بذيرتر شوند(4).

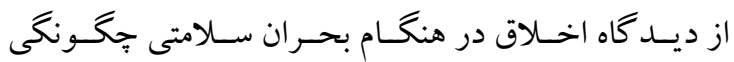
دسترسى بـه مراقبتهــاى بهداشـتى مانــــ دريافـت خـدمات جراحسى در ياسـخخ بـه بحــران و اهميـت دادن بـه يِيامـدهاى سـامت بيمـاران و كـادر درمــانى و مراقبتـى تصـميمات اتخاذشـده توسـط سيسـتم مــديريتى و جر احسـان بـه جـالش كشيده مى شود. تصسميم گيرىهاى فردى در ايسن خصـوص باعث نابسامانى و اتلاف منابع با ارزش و محدود مسىشـود و از سوى ديخر اجراى دستور العمل هاى كلى ابلاغى بدون در نظر كـرفتن شـرايط و امكانـات و دشـوارىهـاى منطقـه اى

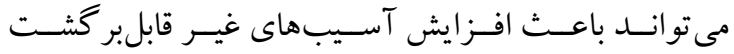
بهسـلامت بيمـار ان و نهايتـاً افززايش بـار اضـافى بـه سيسـتم بهداشـى و درمسانى بشـود. همجنــين آموزمهـاى اخلاقى و
مقدمه

از آنجــا كــهـ كرونــاويــروس 19 •r (COVID-19) در سرتاسر جهان در حال انتشار است، دولتها در حسال انجـام

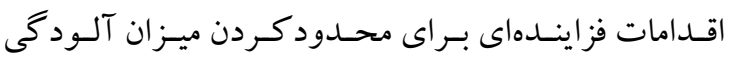
ويسروس هسـتند. بــا افـز ايش تعـــاد مــوارد، بـهـ زودى بــا تصميماتى در مورد محسدودشـدن فضـاى بيمارسـتان روبـرو خــواهيم شـــ. ايسن تصـميمات در بـالاترين سـطح توسـط

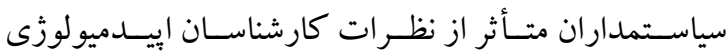
يزشكى و بر اساس موازين اخـلاق يزشـكى در مـورد نحـوه رسيدكى به شرايط اضطرارى بزشكى اتخاذ مى گردد. در 11 مـارس •Y.Y.Y، سـازمان بهداشـت جهـانى (WHO) بيمـارى كرونـا ويسروس 19 •ب (COVID-19) را بـهنـوان يكك بيمارى همه كير جهانى اعلام كرد و شيوع اين بيمارى را بهعنوان يـك فوريـت بين المللى طبقهبنـدى كرد (1). در زمان تهيه اين مقاله، بر اسـاس آخـرين آمـار جهانى بايخـاه اطلاعاتى "worldometer" تـا ايسن لحظه يـكك ميليـون و اسجم هزار و سلو نفر به ويروس كرونـا مبـتلا شـدهاند كـه از اين تعداد، Y هزار و ه9 نفر جان خود را از دست دادهانـد.

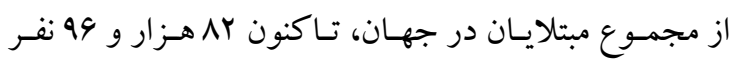
بهبوديافته و توانستهاند اين ويروس را شكست بدهند؛ و اين حاكى از نرخ مركّ و مير بـالاى ايسن بيمـارى اسـت. شـيوع سريع آن، بار بى سابقهاى را به اثربخشى و ويايـدارى سيسـتم مراقبت هاى بهداشتى ما تحميل نموده است. جالشهاى حاد

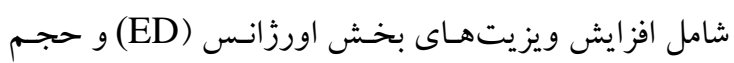
يذ يذش بسـترىهـا، در رابطه بـا خطـر قريسبـالوقوع كمبـود كاركنان مر اقبتهـاى بهداشـتى بـهدليـل مواجـه بـا ويـروس بيمارى تنفسى و تعطيلى كسـترده مراكز بهداشـى درمـانى خصوصى در اين شرايط است(Y). يـس از اعلاميـه سـازمان بهداشـت جهـانى (WHO)، وزارت بهداشـت درمــان و

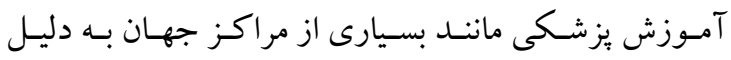
نكر انسى از گسـترش ويـروس لغسو جر احى هــاى انتخـابى در

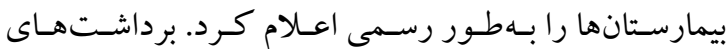
متفاوت از دستور العمل بحث و گفتتخو در سراسر كشـور در مورد ايمنى و امكـان ادامـه انجـام جراحسىهـاى انتخـابى در 
و امكان سنجى و شرايط موجود از نظر امكانـات درمانى و

$$
\text { نيروى انسانى مطرح مى شود: }
$$

مؤلفههاى اصلى حقوق بيمـار مىبايسـت مـورد توجـه قـرار هر بيمارستان و جراح بايد با طرحى براى به حداقل رساندن،

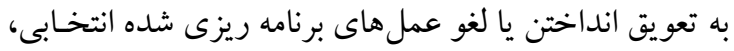

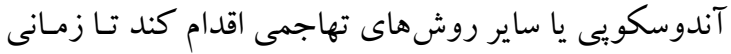

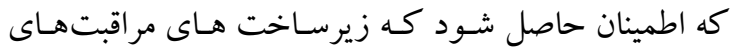
بهداشتى ما مىتواند نيازهاى مهم مراقبت از بيمار را بشتيبانى

استفاده از امكانات ضرورى مورد نياز مر اقبت از بيمـاران، از جمله ICU، تجهيزات محافظ شخصى، وسايل تميز كردن و ونتيلاتورها را بـراى شـر ايط اضطر ارى بـه حـداقل رسـانيد. بسيارى از بيماران بدون علامت وجود دارند كه نـا خواسته ساير بيماران بسترى، سريايى و ارائه دهنـــان مران اقبـتهـاى

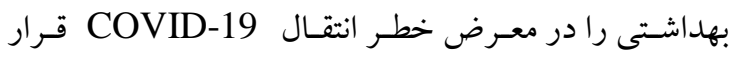

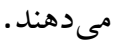
با توجه به همه فرضيات و عدم قطعيت آنها، به نظر مىرسد

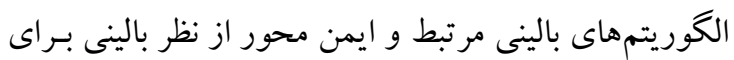

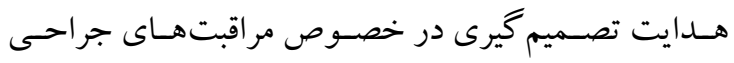

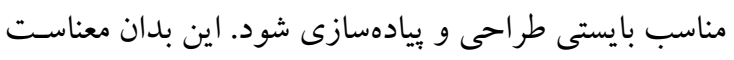

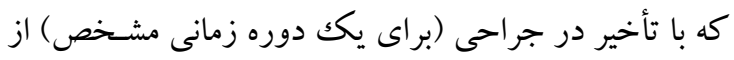
جراحى هاى غير ضرورى اجتناب شود.

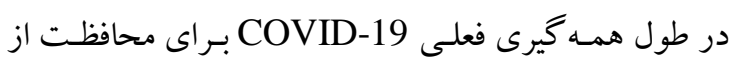

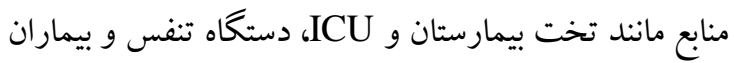
و كار كنان، بهطور كلى توصيه شده است كـه بيمارستانها

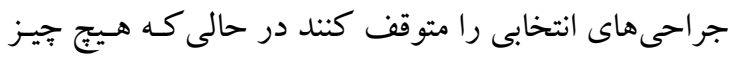

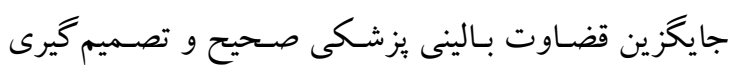

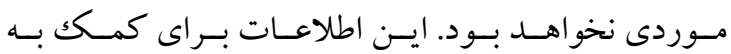
بيمارستانها و ارائهدهند كان خدمت كه با بار فزاينده بيماران COVID-19 روبرو هستند مى تواند راهنماى خوبى بـوده و اين سند در مورد نحوه مـديريت انواع جراحىهـا در طول بيمارى همه كيرى در مراكز آموزشى و درمانى سطح استان

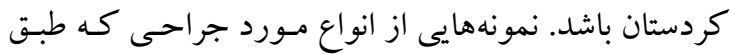
نشانه و فوريت طبقهبندى شدهاند(V)(جدول ()).

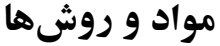
مطالعه حاضر يكك مطالعه مرورى است كه در آن از مقالات مربوط به مطالعات نمايه شده در سايتهاى معتبر انجمن هاى

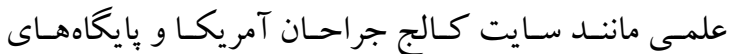
SID, Iranmedex, Magiran, اطلاعـاتى نظير علمسى مات ,Google Scholar, Medline, Scopus, Elsevier, Science Direct ,PubMed مـورد استفاده شـامل جر احى انتخـابى، جراحى ضـرورى،

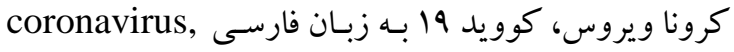
elective surgeries, COVID-19 به زبان انخليسى بـود. ابتدا با استفاده از اين كليدوازههاى انتخـاب شــه بـه وسـيله

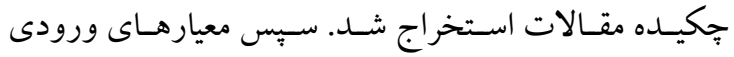
مشخص شده جهت بررسى متن كامل مقاله بدين شرح بود؛؛

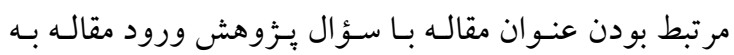
مطالعه شامل: انجام مطالعه در ايـران و جهان كـه مـرتبط بـاـ بيمارىهاى همه گير و جراحىها در اين شرايط بوده است و

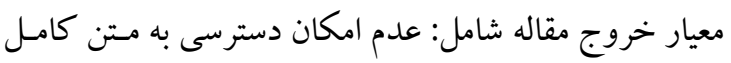

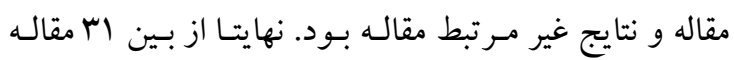
مرتبط كه دارى تمام متن بودند و يسس از اطمينـان از اعتبـار

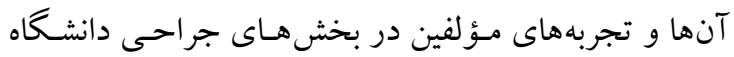

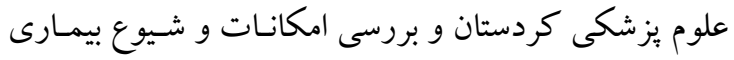
در استان و مشورت با متخصصين اييدميولوزى به جمع بندى

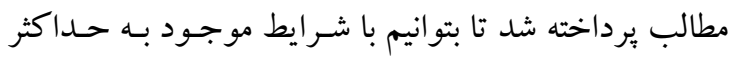

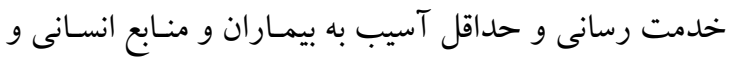
لجستيكى بيردازيم.

\section{يافته ها} توصيههاى زير در مورد جراحىهاى انتخابى و ضـرورى بر

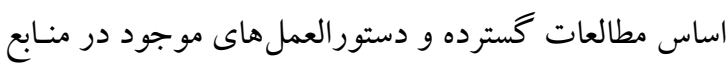


جدول ا. نمونههايى از انواع اعمال جراحى كه طبق نشانه و فوريت طبقهبندى شده

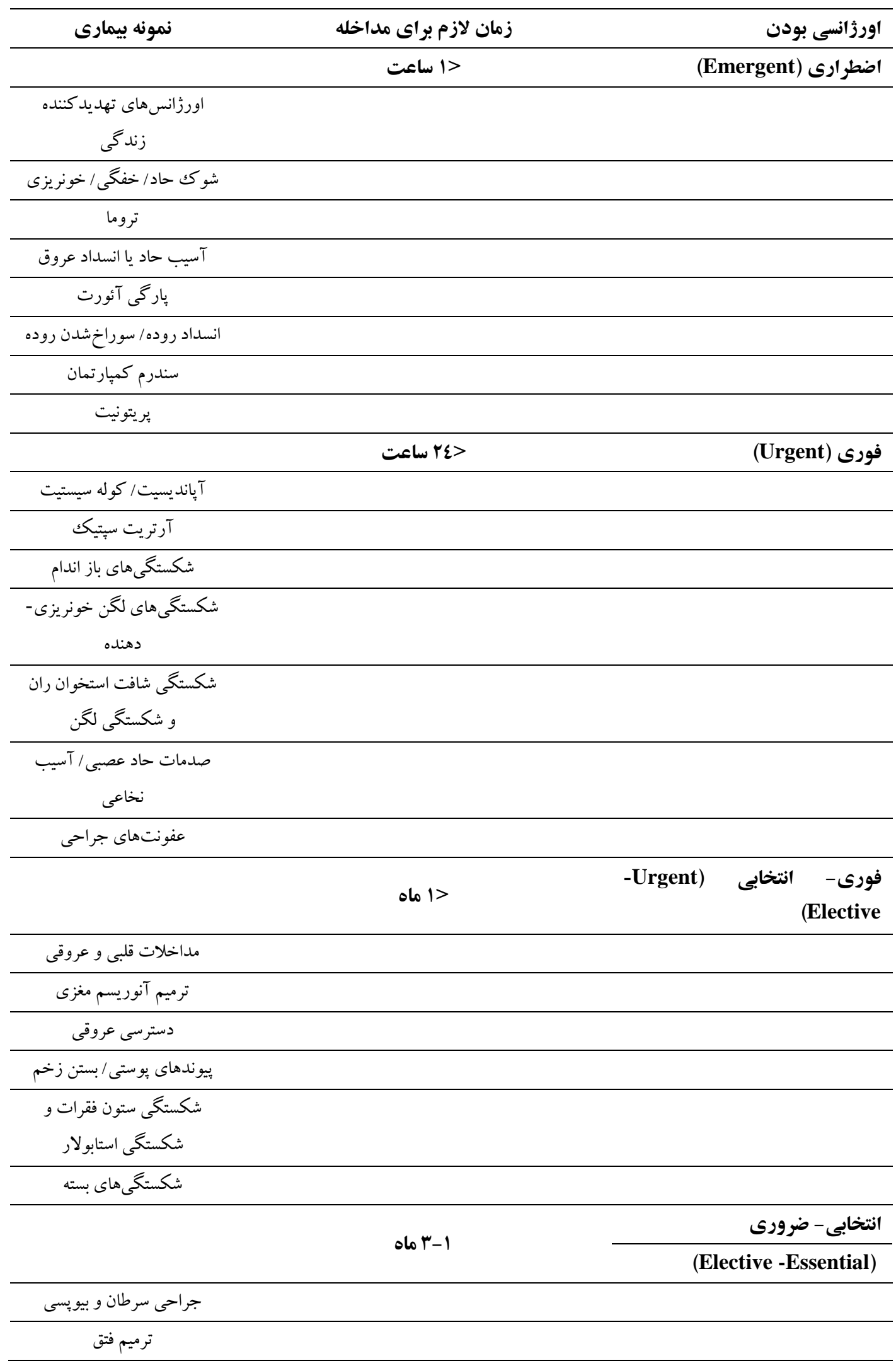




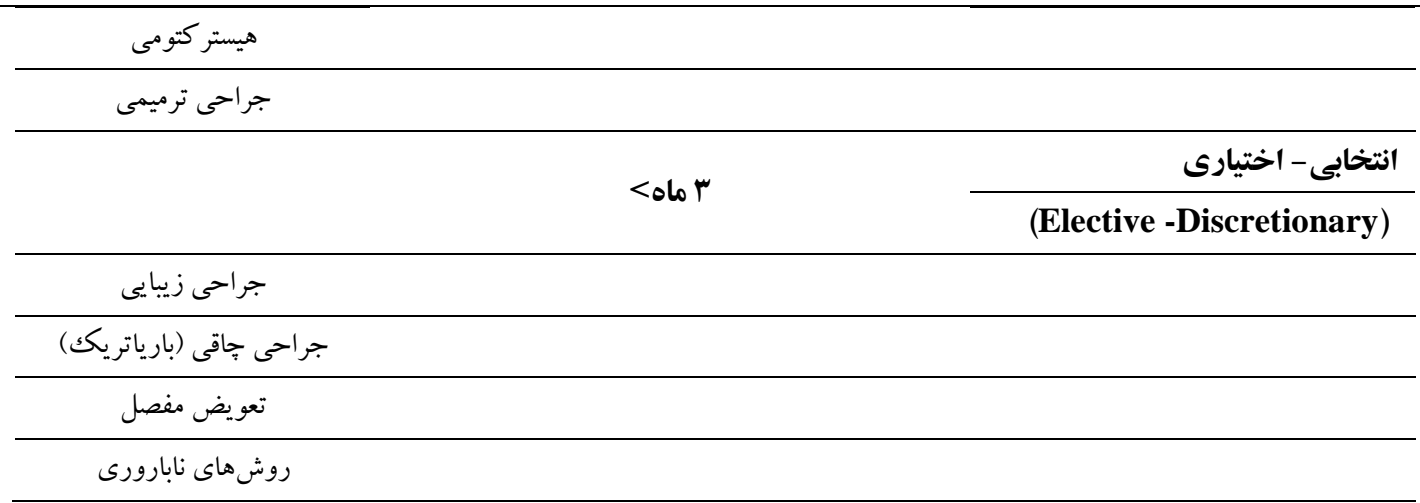

بيماران به دو گروه اورزانس و غير اورزانس (الكتيو) تقسيم مىشوند كه اعمال جراحى اورزانسس در دو گـروه اعمـال جراحى اضطرارى كه تهديد كننده حيات بوده و مىبايسـت در كمتر از ا ساعت مداخله جراحى انجام شود.

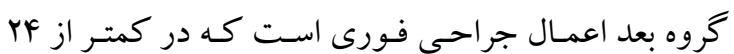
ساعت مداخله جر احى انجام شود. اعمال جراحى الكتيو در سه گروه فورى - انتخابى، انتخـابى - ضرورى و انتخابى - اختيارى تقسيم بندى مىشوند. اعمال الكتيو فورى - انتخابى اعمالى است كه اين بتانسيل را دارد كه بـه سـرعت بـدتر شـود تـا جـايى كـه ممكـن اسـت اضطرارى شود. يذيرش در مدت .ب روز امكان يذير اسـت و بهطور مثال اعمال تعويض دريجه قلب بيمار، قطع عضو و اعمال الكتيو انتخـابى - ضـرورى اعمـالى اسـت كه باعـث ايجاد درد، اختلال در عملكرد يا ناتوانى شـود و بعيـد اسـت كه به سرعت بدتر يا اضطرارى شـود. يـــيرش در مـدت روز امكان يذير است بهطور مثال كوليوسكويى و... اعمال الكتيو انتخابى - اختيارى اعمالى اسـت كـه مىتوانـــ باعث ايجاد درد، اختلال در عملكرد يا ناتوانى شـود و بعيــ است كـه بـه سـرعت بـدتر شـود. يتانسـيل تبـديل شـدن بـه

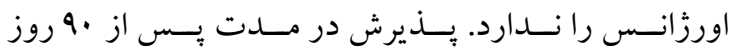
امكانيذير است بهطور مثال اعمال جر احى زيبايى.
بـا محسدود كــــدن روشهــاى جراحسى انتخـابى مى تـوان بـهـ اهداف زير نائل شد: - اهن ا. كـاهش نيـروى انسـانى (جراحسان، متخصسص بيهوشى، يرستاران اسكراب، كاركنان بهداشتى) در اتـاق عمـل بـراى متعادل كردن نيـروى انسـانى و ييشـخيرى از ايجـاد خسـتحى نيروها ضمن حفظ قابليت هاى اقدام فورى COVID-19 كاسـتن سـرايت بيمـارى از مبتلايسان بـه تشـخيص داده نشـده بـا رعايست اصـول محافظـت فـردى و افز ايش باككسازى سطوح

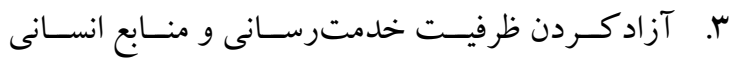
بخش هاى ويثز F. تجزيهو تحليل ريسك بز شكى از طريـق سـنجش نيـاز بـه جراحى انتخابى و خطرات به تعويق افتادن جراحى ه. بررسـى نيـاز بـهـ مر اقبت هــاى بسـترى بعــــ از عمــل در بخشهاى عمومى، در خصوص واحسدهاى مـرتبط بـا اتـاق عمل و ICU در شرايط كنونى كه اضطراب گسترده در مـورد همـهـ گيرى COVID-19 وجـود دارد طراحسى يـك راهنمـاى عملى مبتنى بر طبقهبندى خطر بر اساس منابع علمى ضرورى به نظر مىرسد كه در نمودار ا به آن مىبردازيد. تقسيمبندى اعمال جراحى: 


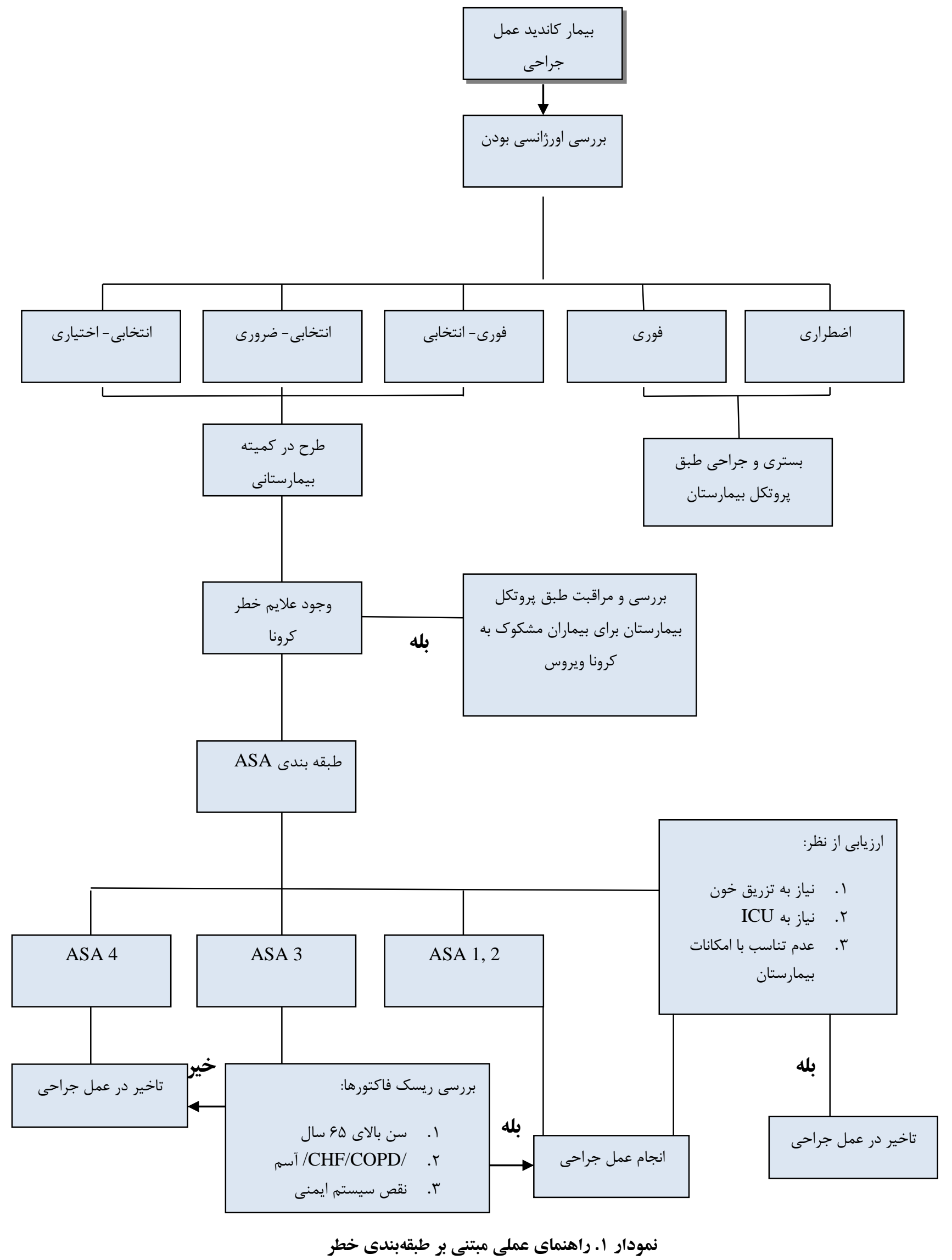

هبلم علمى دانشكاه علوه يِشكى كردستان / دوره بيست و شش / ذرداد و تير •معا| 
انسداد ثانويه در فتق گير كرده شـده مراجعـه مى كنــد، بايسـ تحـت عمل جراحسى فورى قـرار گيرنسـ. مـديريت درمـان

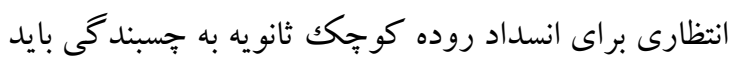
از روش معمول بيروى كند. آيانديسيت، بدون عارضه: شواهدى وجود دود دارد كه نشان مىدهد بيماران مبتلا به آيانديسيت بدون عارضه را مىتوان

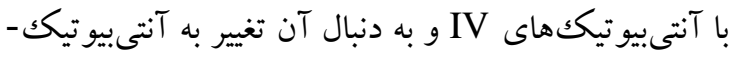

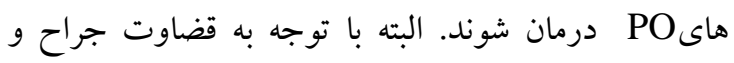

وضعيت بيمار، آنتى بيو تيك در نظر كرفته مى شود ( •).

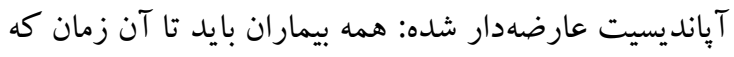

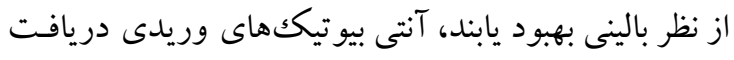

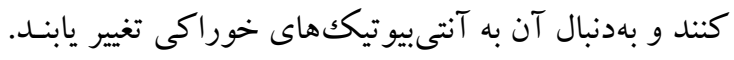

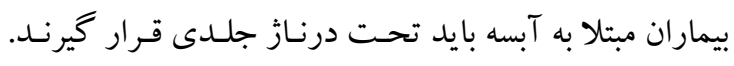

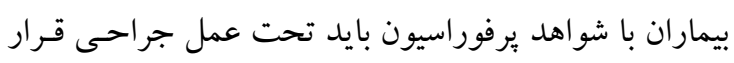
كيرند.

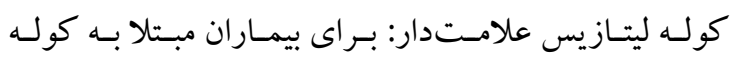
ليتازيس علامتدار و كوله سيستيت مزمن بايد درد را كنترل

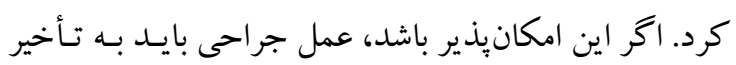

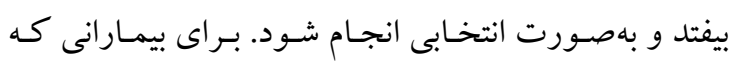

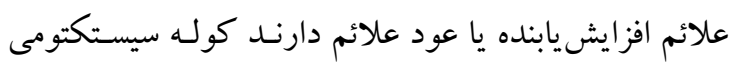
لإِاروسكويى در نظر كرفته شود. كولدو كوليتيازيس (سنگك مجارى صفر اوى): بيمـاران مبتـلا

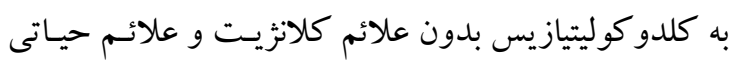
بايدار ممكن است به صورت انتظارى درمان شوند. كوله سيستيت حاد: بيماران سالم مبتلا به كوله سيستيت حساد بايد تحت عمل كوله سيستكتومى لإياروسكويى قرار بحيرند

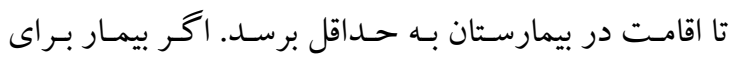

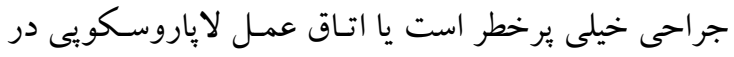

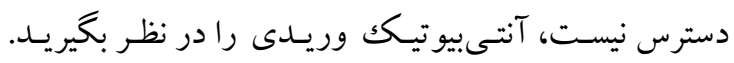

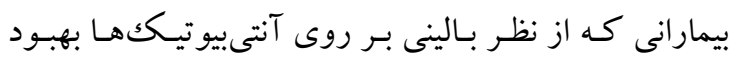

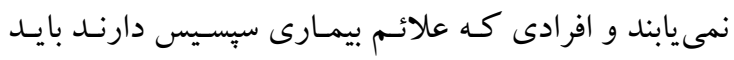
علاوه بر تجويز آنتىبيوتيككهاى وريدى، تحت عمل كوله

$$
\text { سيستوستومى قرار بخيرند. }
$$

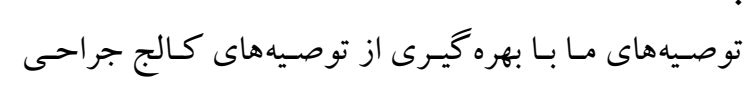

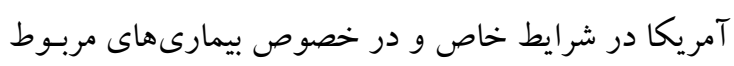

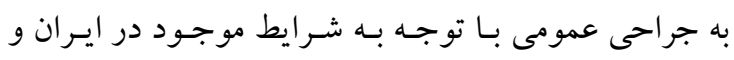
منطقه كردستان بدين شرح است(^):

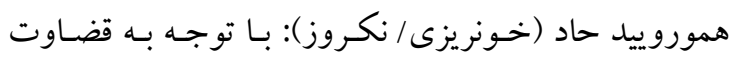

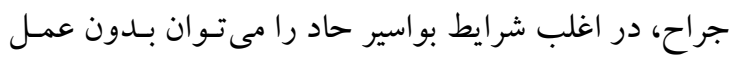

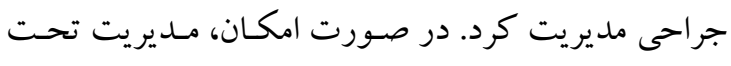
بى حسى موضعى در يكك مر كز سريايى ممكن است مناسـب مدرب

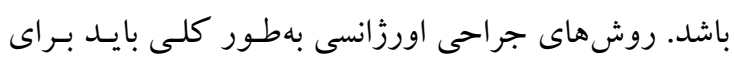

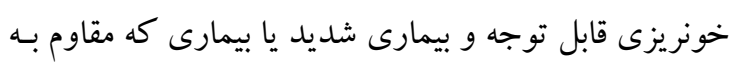
درمان غير جراحى است، انجام شود.

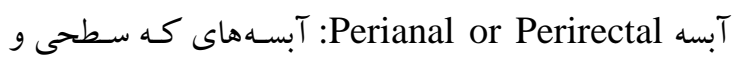

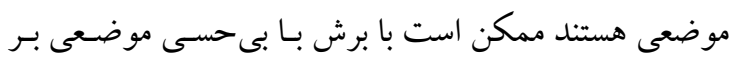

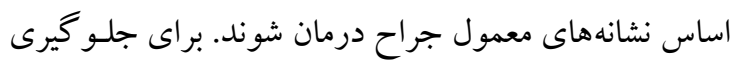
از گسترش بيمارى به يكك عفونت تهاجمى و كو تـاه كردن

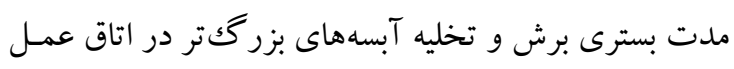
بايد صورت گيرد. عفونتهاى بافت نرم: آبسه هاى سطحى و موضسعى ممكن

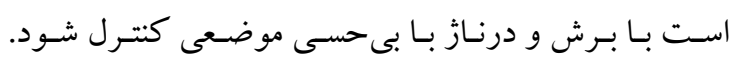

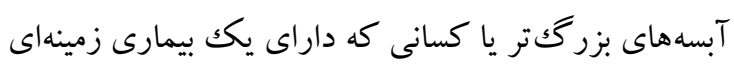

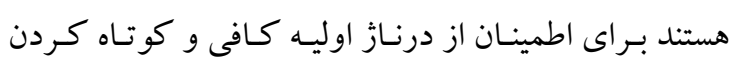

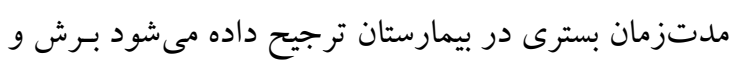
تخليه در اتاق عمل انجام شود.

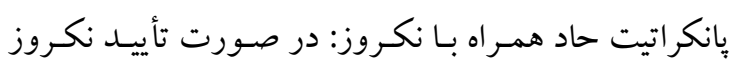

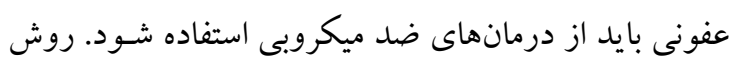

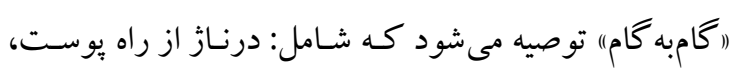

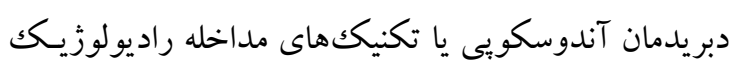

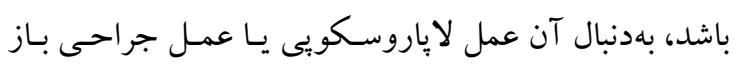

$$
\text { انجام مىشود (9). }
$$

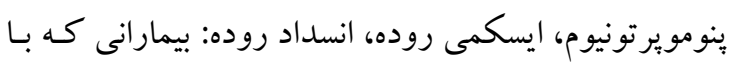

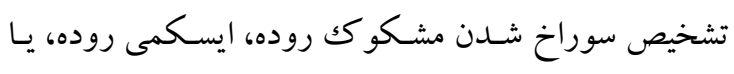


| 10 براهى هاى انتخابى (الكتيو)...

$$
\begin{aligned}
& \text { F.بيويسىهاى احتمالاً بدخيم } \\
& \text { ه.برش و تخليه آبسه سينه }
\end{aligned}
$$

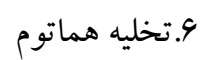

$$
\begin{aligned}
& \text { Vلبٍ ماستكتومى ايسكميك. V. }
\end{aligned}
$$

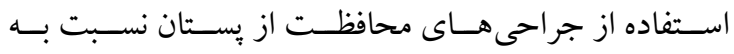
ماستكتومى / يا بازسازى تا زمان حلشدن بيمـارى همـه گير

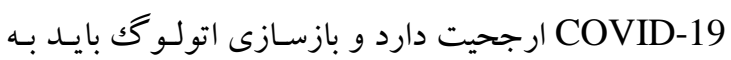

تعويق افتد. مواردى كه بايد به تعويق افتاد: ا.برداشتن ضايعات خوش خيم -فيبرونونوما، ندولها و غيره r.بيو يسى هايى احتمالاً خوش خيم هستند. r.ضايعات در معرض خطر مانند آتيى، ياييلوماو غيره F.جراحى بيشخير انه در موارد سرطان و غير سرطان

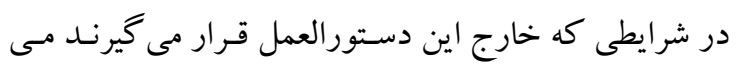
بايست در كميتهاى كه شامل متخصص جراحى و متخصص بيهوشى و كارشناس برستارى از خرووه مـديريت بيمارسـتان مىباشد مطرح و در خصوص اينكه عمل جراحى مى توانــ به تأخير بيفتد تصميم گرفته شـده و در صـورت تائيـد ايسن كميته اقدام لازم انجام شود. تغيير استراتزىهاى ذكر شده در اينجا بسيار محتمـل اسـت؛ زيرا دركك ما از جالشهاى منحصر به فردى كه - COVID 19 در هـر زمـان و مكـانى ايجـاد مسى كنــ، تغييراتسى رادر

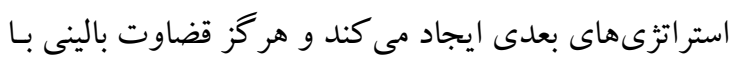
جيز ديخرى جايخزين نخواهد شد. بيمارى همه گير COVID-19 بهسرعت در حسال كسترش است و سيستمهاى بهداشتى را در سراسر جهان تحتالشعاع قــرار مى دهـــ. در برخــورد بــا COVID-19، جر احسـان و

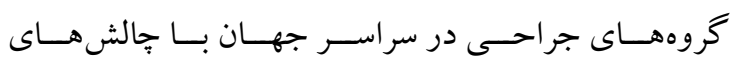
منحصربهفرد در كارهاى روزمـره روبـرو هسـتند. اميـدواريم تجربيات خود را از منظر گروه جراحى بيمارستان آموزشى دانشگاه علوم بزشكى كردستان در مـورد اقـدامات خـود در ״ِاسخ به اين جالش به اشتر اكك بحذاريم، با اين اميـد كـه در طول اين بحران جهانى اين تجربيات به نفع ديخران نيز باشد.

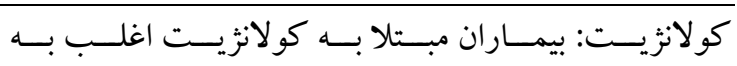

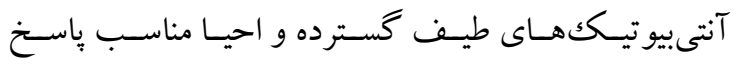
مىدهند. براى بيمارانى كه از نظر بـالينى بهبـود نمىيابنـد و مبتلايسـان بـه سرٍـيس، ERCP و اسـفنكتروتومى توصسيه مىشود. در صورت وجود نكخرانى در مـورد كوله سيستيت همز مـان، ممكـن اسـت كولـه سيستوسـتومى از راه يوسـت مناسب باشد. ديورتيكوليت: ديورتيكوليت بدون عارضه با مراقبت معمول قابل كنترل است كه شامل آنتىبيو تيككهاى وريدى و تبديل به آنتىبيو تيككهـاى خـوراكى اسـت. بيمـاران بـا بريتونيـت

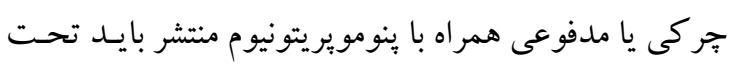
عمل جراحى قرار گيرند.

\section{جراحى سرطان كولور كتال:} مواردى كه بايد در اسرع وقت انجام شود(1):

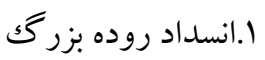
ץ.انسداد سرطانى ركتوم

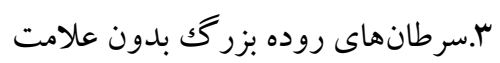

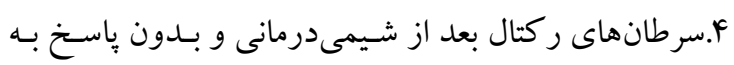
درمان ه.نگخ انى در مورد سوراخ شدن 9.سرطانهاى ركتال در مرحله اوليه كه درمان كمكى بـراى آنها مناسب نيست تشخيص هايى كه مى تواند ب ماه به تعويق بيفتد:

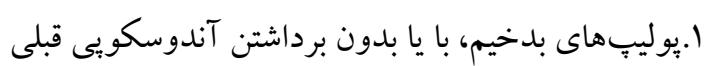

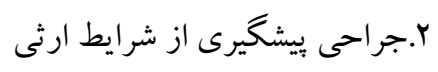

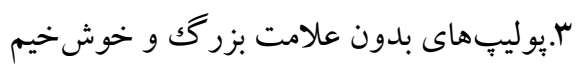

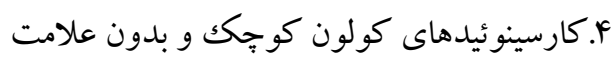

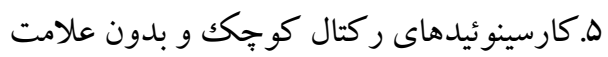

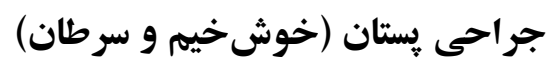
مواردى كه بايد در اسرع وقت انجام شود: ا.بيمارانى كه شيمى درمانى آنها به اتمام رسيده

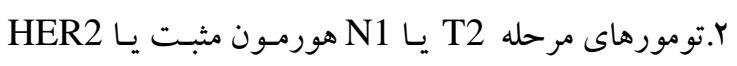

منفى

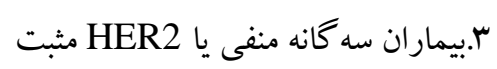




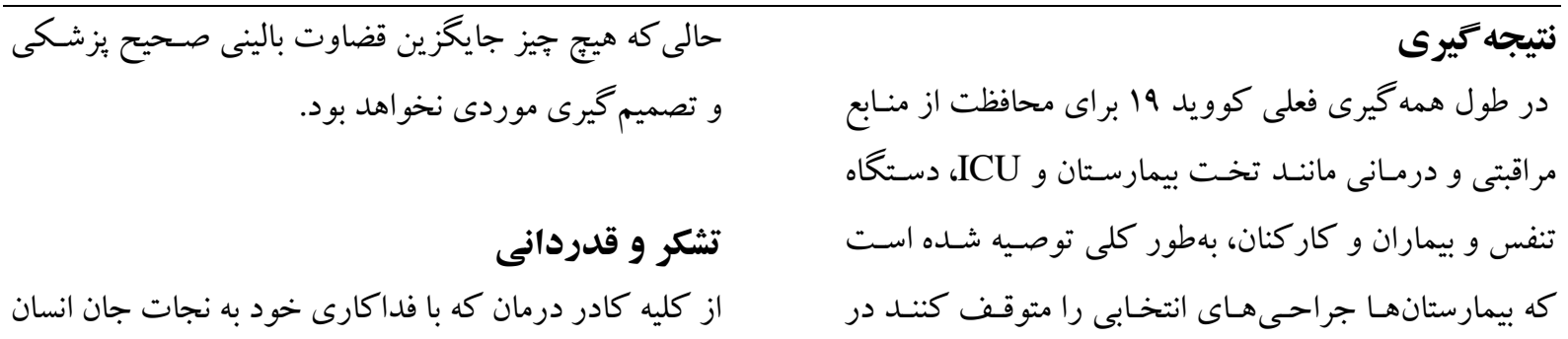

1.McKay B, Calfas J, Ansari T. Coronavirus declared pandemic by World Health Organization. The Wall Street Journal. 2020 Mar 11.

2.UNICEF. Covid-19 educationaldisruptionandresponse. 2020..

3.Evans M, Wilde MA. Hospitals push off surgeries to make room for coronavirus patients. The Wall Street Journal. 2020 Mar 16.

4.Martines J. UPMC shuns health experts' calls to cancel elective surgeries. Pittsburgh TribuneReview, 17, 2020.

5.Sathya C. Your elective surgery will be canceled. It's for everyone's good. The Washington Post, March 16, 2020.

6.Zhang S. What it really means to cancel elective surgeries: to make room for coronavirus patients, hospitals are delaying procedures that would make major differences in people's lives. The Atlantic, 17, 2020.

7.Stahel P.F. How to risk-stratify elective surgery during the COVID-19 pandemic?. Patient Saf Surg. 2020; $14: 8$

8.American College of Surgeons (ACS). COVID-19 update: guidance for triage of non-emergent surgical procedures. March 13, 2020. (www.facs.org).

9.van Santvoort HC, Besselink MG, Bakker OJ, Hofker HS, Boermeester MA, Dejong CH, van Goor H, Schaapherder AF, van Eijck CH, Bollen TL, van Ramshorst B. A step-up approach or open necrosectomy for necrotizing pancreatitis. N Engl J Med. 2010;362(16):1491-502.

10.Mahida JB, Lodwick DL, Nacion KM, Sulkowski JP, Leonhart KL, Cooper JN, et al. High failure rate of nonoperative management of acute appendicitis with an appendicolith in children. J Pediatric Surg. 2016;51:908-11.

11.Yu GY, Lou Z, Zhang W. Several suggestion of operation for colorectal cancer under the outbreak of Corona Virus Disease 19 in China. Zhonghua Wei Chang Wai Ke Za Zhi. 2020;23(3): 9-11. 